\title{
UTILIZATION OF FERMENTED CASTOR OIL SEED (RICINUS COMMUNIS, L) MEAL IN DIETS FOR COCKEREL CHICKS
}

\author{
UTILIZACIÓN DE HARINA DE SEMILLA DE RICINO (RICINUS COMMUNIS, L) \\ FERMENTADAENDIETASPARA POLLOS
}

\author{
Oso, A.O. ${ }^{1 *}$, Olayemi, W.A. ${ }^{1}$, Bamgbose, A.M. ${ }^{1}$ and Fowoyo, O.F. ${ }^{2}$
}

${ }^{1}$ College of Animal Science and Livestock Production. Department of Animal Nutrition. University of Agriculture Abeokuta. PMB 2240. Ogun State. Nigeria. West Africa. *drosoann@yahoo.com ${ }^{2}$ College of Animal Science and Livestock Production. Department of Animal Physiology. University of Agriculture Abeokuta. PMB 2240. Ogun State. Nigeria. West Africa.

\section{AdDITIONAL KEYWORDS}

Nutrient digestibility. Haematology. Carcass yield.

\section{SUMMARY}

The effect of including 0,50, 100 and $150 \mathrm{gkg}^{-1}$ of fermented castor oil seed (FCSM) meal in the diets of 160 day old chicks of Nera strain, on performance, nutrient digestibilities, haematology and carcass yield, was assessed for 56 days. The final live weight, weight gain, feed intake and feed conversion ratio were affected $(p<0.05)$ by treatments. The final live weight decreased $(p<0.05)$ as FCSM increased in the diets. There were no differences in the weight gain of chicks fed control and $50 \mathrm{gkg}^{-1}$ FCSM diet. The apparent nutrient digestibility of chicks fed control diets were higher $(p<0.05)$ than those fed other dietary treatments. Chicks fed control diets recorded the highest $(p<0.05)$ carcass yield in terms of plucked and eviscerated weight. These values obtained in chicks fed $50 \mathrm{gkg}^{-1}$ were higher $(p<0.05)$ than those fed 100 and $150 \mathrm{gkg}^{-1} \mathrm{FCSM}$. There were no differences in back, breast, gizzard, and intestines weights. The white cell and platelet counts were affected $(p<0.05)$ for chicks fed 100 and $150 \mathrm{gkg}^{-1}$ FCSM diets. Higher $(p<0.05)$ values of serum creatinine were obtained in chicks fed 100 and 150 $\mathrm{gkg}^{-1}$ FCSM. FCSM could successfully be included in chick starter diets at $50 \mathrm{gkg}^{-1}$ inclusion.

\section{RESUMEN}

Durante 56 días, se estudió el efecto de incluir $0,50,100$ y $150 \mathrm{~g} \mathrm{~kg}^{-1}$ de harina de semilla de ricino fermentada (FCSM) en las dietas de 160 pollos de un día (línea Nera), sobre la producción, digestibi-

Recibido: 16-10-08. Aceptado: 5-5-09.

\section{Palabras clave adicionales}

Digestibilidad. Hematología. Rendimiento canal.

lidad, hematología y rendimiento canal. El peso vivo final, la ganancia de peso, la ingestión y conversión de alimento fueron afectadas $(p<0,05)$ por los tratamientos. El peso vivo final disminuyó $(p<0,05)$ al aumentar la inclusión de FCSM. No hubo diferencias de peso vivo en los pollos que consumieron las dietas con 0 y 50 mg. $\mathrm{kg}^{-1}$ de FCSM. La digestibilidad aparente de los nutrientes en los pollos con la dieta control fue más alta $(p<0,05)$ que en los que consumían FCSM. Los pollos de la dieta control consiguieron los mejores rendimientos de canal en términos de peso desplumado y eviscerado; estas variables fueron también más altas con 50 mg. $\mathrm{kg}^{-1}$ que en los demás tratamientos. No hubo diferencias en los pesos de dorso, pechuga, molleja, e intestinos delgado y grueso. Los recuentos de leucocitos y plaquetas fueron afectados por igual en las dietas 100 y 150 $\mathrm{mg} \cdot \mathrm{kg}^{-1}$, niveles a los que también fueron registrados los mayores niveles de creatinina. La FCSM puede incluirse con buenos resultados al nivel de $50 \mathrm{mg} \cdot \mathrm{kg}^{-1}$ en las dietas de arranque de pollos.

\section{INTRODUCTION}

Plant protein and oil seeds used in livestock feed formulation over the years have suffered serious competition between man, livestock and agro-industries. Hence, there is a need to explore alternative protein sources to reduce the competition. Castor 


\section{OSO, OLAYEMI, BAMGBOSE AND FOWOYO}

oil bean (Ricinus communis) is grown in tropical and temperate regions, where the dehulled seeds are processed for use as flavour-enhancing food condition.

Studies in animal nutrition have shown that castor oil bean meal can be used as a protein supplement for ruminants, rabbits, pigs and chicks (Okorie et al., 1985). However, its utilization in monogastrics, especially poultry, has been limited because of possible deleterious effect due to the presence of ricin, a poisonous protein component, ricinine, an alkaloid, and thermostable castor allergen (Vilhjalmsdottir and Fischer, 1971; Okoye et al., 1987). Ricin is a group of phytotoxin which is toxic, antigenic, thermolabile and agglutinating red blood cell while ricinine is a white alkaloid usually extracted with the oil (Jerkins, 1963). The complex allergen represents about $12.5 \%$ of weight of the cake. It is a protein composed of nontoxic, thermally stable, but with allergenic actions (Carrielo-Gama, 2006; Machado and Silver, 1992). The castor allergen according to Thorpe et al. (1988) caused congestion of the nose, eyes, resulting in vomiting, gastroenteritis, hepatic and renal damage.

In the quest to removing these deleterious factors, various aqueous heating, combined extraction and heat treatment procedures have therefore been developed. Adedeji et al. (2006) assessed the utilization of boiled castor seed cake in diet for weaner rabbits and observed a tolerant level of not more than $15 \%$. The feeding value of castor bean in diets for growing chicks can be improved by roasting. Puttaraj et al. (1993) explored the reduction of the antinutritional factors using lime cum heat treatment and obtained a good response with rats. Roasting of the castor seed followed by oil extraction in the hammer mill resulted in the reduction of the deleterious factor (Pablo et al., 1976).

Researches are currently on going to discover physical and chemical treatments (Anandan et al., 2005) that will improve the inclusion of this meal in poultry nutrition while maintaining its nutritive quality. Ani and Okorie (2002) in their studies explored the possibility of reducing these deleterious factors by cooking and dehulling the seeds and they reported a reduced feed intake and weight gain in finishing broilers fed 15\% inclusion level and above.

However, there is limited information on the possible reduction of the deleterious factor using locally acceptable medium of soaking and natural fermentation which could be acceptable by peasant and large scale farmers. Hence, this study was carried out to ascertain the effect of replacing soybean meal with graded levels of air tight, water soaked, naturally fermented castor oil seed (FCSM) and its effect on the performance, nutrient digestibility, haematological parameters and carcass characteristics of cockerel starters.

\section{MATERIALS AND METHODS}

\section{TEST INGREDIENT}

The castor seed used in the study was obtained from the Raw Material Research and Development Council, Kaduna, Nigeria. The seeds were soaked in water to allow natural fermentation at a ratio of 1:4 under an air tight environment for 5 days. The water was drained off at end of the fermentation process, seeds were washed several times with water to remove the sour taste and fermenting odour. The washed seeds were then sun dried to a moisture content of $100-120 \mathrm{gkg}^{-1}$. The seed were later hammer milled and screw pressed to obtain the meal while the oil drained off using the manual hydraulic extractor. The milled samples were later packaged and used to compound the experimental diets.

\section{EXPERIMENTAL MANAGEMENT AND DESIGN}

One hundred and sixty day old cockerels of Nera strain were allotted to four diets containing $0,50,100$ and $150 \mathrm{gkg}^{-1}$ FCSM in a completely randomized design. Each dietary treatment consisted of 40 birds 


\section{UTILISATION OF CASTOR SEED MEAL IN COCKEREL CHICKS}

replicated 4 times with 10 birds per replicate. The experiment lasted for 8 weeks during which feeds and water were offered ad libitum. Feeding was done daily while the feed intake on a daily basis was computed as the difference between the feed offered and leftovers. The chicks were weighed weekly while weight gain was computed as the difference between the final liveweight and initial weight. Feed conversion ratio was computed as the ratio of the total feed consumed to weight gain. The proximate composition of the feed samples were determined according AOAC (1990).

\section{MEASUREMENT OF NUTRIENT METABOLIZITY}

At the end of the experiment, two birds per replicate were housed individually in metabolic cages. Three days acclimatization period were allowed prior to the start of the trial. Known weights of feed were given the birds and total feacal droppings were collected, dried and samples assayed on dry matter basis for proximate constituents. The proximate constituents were used to calculate the nutrient metabolizity of each constituent. Gross energy of the feed and faecal droppings was determined using the calorimeter bomb.

\section{SERUM AND HAEMATOLOGICAL PARAMETERS}

Blood samples $(2.5 \mathrm{ml})$ were collected at 8 weeks according to the procedure of Varley et al. (1980) via the wing vein of two birds per replicate into ethytlene diamine tetraacetic acid (EDTA) bottles for haematological analysis while another set were collected into vials without EDTA and allowed to clot as outlined by Baker and Silverton (1985). The serum from the clotted blood samples were used to determine the serum biochemistry. The packed cell volume (PCV), red blood cell (RBC), haemoglobin $(\mathrm{Hb})$ and white blood cell (WBC) were determined using Wintrobes microhaematocrit and improved Neubauer haemocytometer as described by Baker and Silverton (1985). The total serum protein (TSP) was determined according to the method of Colowich and Kaplan (1955) while the serum albumin (SA) and globulin (SG) was determined using bromocresol purple method of Varley et al. (1980). Serum creatinine (SC) was determined using the principle of Jaffe reaction as described by Bonsnes and Tausslay (1945) while the serum uric acid (SUA) was determined using the Kit (Quinica clinica spam) as described by Wootton (1964).

\section{Carcass evaluation}

At the expiration of the experiment, 8 birds per treatment ( 2 birds per replicate) were selected and used for the carcass evaluation. The birds were slaughtered via neck slit, defeathered, dressed and cut into parts according to the procedure outlined by Oluyemi and Robert (1979). Each of the parts were weighed and recorded.

\section{StATISTICAL ANALYSIS}

Data collected were laid out as completely randomized design and analysed with oneway Analysis of Variance using SPSS (1999). Model sum of squares were partitioned to test linear, quadratic and cubic trend (Gomez and Gomez, 1983).

\section{RESULTSANDDISCUSSION}

\section{CHEMICAL COMPOSITIONOF FERMENTED CAS- TOR SEED MEAL (FCSM)}

Table I shows the proximate composition of the FCSM used in this study compared with soya bean meal. FCSM has a lower crude protein and $\mathrm{P}$ level of $242.0 \mathrm{gkg}^{-1}$ and $1.70 \mathrm{gkg}^{-1}$ than SBM which was reported by Aduku (2000) to have crude protein and $P$ level of $440.0 \mathrm{gkg}^{-1}$ and $6.0 \mathrm{gkg}^{-1}$. However, the ether extract, ash, NFE, dry matter, crude fibre and Ca contents of FCSM were found to be higher than that of the SBM. The proximate composition obtained for FCSM in this study was similar to the findings of Okorie et al. (1987) who reported that the crude protein of castor oil seed meal ranged 
Table I. Proximate composition offermented castor seed meal (FCSM) and soya bean meal (SBM) on dry matter basis. (Composición de harina de semilla de ricino fermentada (FCSM) y harina de soja (SBM), sobre materia seca).

\begin{tabular}{lcc}
\hline Proximate fraction & \multicolumn{2}{c}{ Composition $\left(\mathrm{gkg}^{-1}\right)$} \\
& FCSM & ${ }^{*} \mathrm{SBM}$ \\
\hline Crude protein & 242.0 & 440.0 \\
Crude fibre & 125.2 & 65.0 \\
Ether extract & 73.8 & 35.0 \\
Ash & 84.9 & 60.0 \\
Nitrogen free extract & 436.7 & 400.0 \\
Dry matter & 915.1 & 892.0 \\
Calcium & 7.2 & 2.0 \\
Phosphorus & 1.7 & 6.0 \\
Gross energy (MJ/kg) & 16.91 & 19.46 \\
\hline
\end{tabular}

*Aduku (1993).

between 240-320 $\mathrm{gkg}^{-1}$ depending on processing. The crude protein, crude fibre, ether extract, ash and nitrogen free extract values obtained in this study were however lower than the value reported by Adedeji et al. (2006) who reported values of 390, 190, 70,80 and $430 \mathrm{gkg}^{-1}$ respectively. The composition of the experimental diets as revealed in table II shows that the metabolizable energy of the diet reduced as the level of FCSM inclusion increased in the diet from $10.94 \mathrm{MJ} / \mathrm{kg}$ (in control) to 10.54 $\mathrm{MJ} / \mathrm{kg}$ (150 $\mathrm{gkg}^{-1} \mathrm{FCSM}$ based diet). This was due to the fact that FCSM had a lower gross energy than SBM and replacing SBM with FCSM will eventually leads to a lower energy based diet.

\section{GROWTH PERFORMANCE AND NUTRIENT DIGESTIBILITY}

Performance characteristics and nutrient digestibility of cockerel chicks fed FCSM based diet is shown in table III. The final live weight and average weight gain of the chicks reduced $(\mathrm{L}, \mathrm{Q} ; \mathrm{p}<0.05)$ with increased dietary level of FCSM. However, the average weight gain recorded in the control diet and chicks placed on $50 \mathrm{gkg}^{-1}$ FCSM based diet recorded similar values. The similarity observed among the groups fed control and $50 \mathrm{gkg}^{-1}$ FCSM based diets could be related to their similar energy values, since chicks have been reported to consume feeds in order to first fulfill their energy requirements (Gibson et al., 1989). The linear (L; $<<0.01)$ and quadratic decline $(\mathrm{Q} ; \mathrm{p}<0.05)$ in the feed intake and weight gain observed with corresponding increase in FCSM inclusion level from chicks fed control diet to those fed with $100 \mathrm{gkg}^{-1} \mathrm{FCSM}$ was in agreement with the findings of Okorie et al. (1987) who reported that broiler starter fed heat treated castor seed meal based diets at 150 and 200 $\mathrm{gkg}^{-1}$ inclusion level exhibited a reduced performance in terms of feed intake, weight gain and feed conversion ratio. This could

Table II. Gross composition of diets. (Composición de las dietas).

\begin{tabular}{lcccc}
\hline & \multicolumn{4}{c}{ Diets } \\
& $\mathrm{T} 1$ & $\mathrm{~T} 2$ & $\mathrm{~T} 3$ & $\mathrm{~T} 4$ \\
\cline { 2 - 5 } Ingredients $\left(\mathrm{gkg}^{-1}\right)$ & & & & \\
FCSM & 0 & 50 & 100 & 150 \\
Maize & 450.0 & 450.0 & 450.0 & 450.0 \\
Soybean meal & 150.0 & 100.0 & 50.0 & 0.0 \\
Fish meal $(72 \% \mathrm{CP})$ & 10.0 & 10.0 & 10.0 & 10.0 \\
Blood meal & 25.0 & 40.0 & 50.0 & 65.0 \\
Wheat offal & 270.0 & 250.0 & 240.0 & 230.0 \\
Palm kernel cake & 50.0 & 50.0 & 50.0 & 50.0 \\
Bone meal & 25.0 & 25.0 & 25.0 & 25.0 \\
Oyster shell & 15.0 & 15.0 & 15.0 & 15.0 \\
Premix & 2.5 & 2.5 & 2.5 & 2.5 \\
Salt & 2.5 & 2.5 & 2.5 & 2.5 \\
& & & & \\
Determined analysis & $\left(\mathrm{gkg} \mathrm{k}^{-1}\right)$ & & & \\
ME (MJ/kg) & 10.9 & 10.8 & 10.7 & 10.5 \\
Crude protein & 175.6 & 175.1 & 174.9 & 174.5 \\
Crude fibre & 36.3 & 39.3 & 42.3 & 45.3 \\
Dry matter & 873.5 & 872.1 & 871.0 & 870.0 \\
Ash & 35.2 & 40.1 & 42.1 & 46.0 \\
Calcium & 16.1 & 16.5 & 17.0 & 17.3 \\
Phosphorus & 7.9 & 7.5 & 7.1 & 6.9 \\
Lysine* & 7.5 & 7.2 & 6.9 & 5.5 \\
Methionine* & 2.9 & 2.6 & 2.4 & 2.2 \\
\hline & & & &
\end{tabular}

*Source: Aduku (2000). 


\section{UTILISATION OF CASTOR SEED MEAL IN COCKEREL CHICKS}

also be due to the residual effect of the antinutritional factors present in the meal which increased with increase in the level of FCSM in the diet. There has been reports of reduced growth response in poultry due to residual effect of castor allergen in castor bean meal based diets (Okorie et al. (1987); Margeret et al., 1979). As the FCSM inclusion level increased, there was also a dilution effect of fibre on the diets reducing the utilization of other nutrients in the body of the chicks. This is in agreement with the report of Longe and Ogedengbe (1989) which stated that diluting diets with fibre source contributed immensely to the bulkiness of the resultant diets, hence reducing nutrient digestibilities. This dilution effect reduced the actual nutrient intake by the birds most especially protein intake. This caused the reduced linear and quadratic trend in $(\mathrm{L}, \mathrm{Q} ; \mathrm{p}<0.05)$ protein digestibility and dry matter digestibility as the level of FCSM in the diet increased. This reduced nutrient digestibility and intake as
FCSM inclusion increased could go a long way to reduce the actual protein intake and also lead to a lower resultant body weight gain of broilers as FCSM inclusion level increased. This was also confirmed by the reports of Gibson et al. (1989) who reported that body weight gain of broilers reduced with decrease in dietary protein and performance. The absence of mortality recorded in this study however was contrary to the reports of Ani and Okorie (2002) who reported that $150 \mathrm{gkg}^{-1}$ castor oil bean based diet caused $(p<0.05)$ mortality in chicks. The absence of mortality in this study could be due to fermentation which reduces the toxicity level of the antinutritive factors in castor oil bean. Significant differences observed in this study for feed intake, weight gain and feed conversion ratio were similar with the report of Ani and Okorie (2002).

The dietary treatment has no effect on ether extract digestibility while exhibiting a quadratic increase $(Q ; p<0.05)$ in crude fibre digestibity. However, the dry matter

Table III. Performance characteristics and nutrient digestibility in cockerel chicks fed experimental diets. (Rendimiento y digestibilidad de nutrientes en pollitos alimentados con las dietas experimentales).

\begin{tabular}{|c|c|c|c|c|c|c|c|c|}
\hline \multirow[b]{3}{*}{ Parameters } & \multicolumn{4}{|c|}{ Levels of inclusion of FCSM $\left(\mathrm{gkg}^{-1}\right)$} & \multirow{3}{*}{ SEM } & \multicolumn{3}{|c|}{ Probability $^{1}$} \\
\hline & 0 & 50 & 100 & 150 & & L & Q & $\mathrm{C}$ \\
\hline & $\mathrm{T} 1$ & $\mathrm{~T} 2$ & T3 & T4 & & & & \\
\hline Initial body weight (g/bird) & 35.0 & 35.0 & 35.0 & 35.0 & 0.12 & NS & NS & NS \\
\hline Average final live weight (g/bird) & 560.0 & 555.8 & 480.4 & 450.2 & 15.63 & ** & * & NS \\
\hline Average weight gain (g/bird) & 525.0 & 520.8 & 445.4 & 415.2 & 24.00 & ** & * & NS \\
\hline Average feed intake $(\mathrm{g})$ & 1785.0 & 1977.7 & 1848.4 & 1893.3 & 60.83 & ** & * & NS \\
\hline Feed conversion ratio & 3.40 & 3.79 & 4.15 & 4.56 & 0.34 & $* *$ & * & NS \\
\hline Mortality (\%) & 0 & 0 & 0 & 0 & 0.00 & NS & NS & NS \\
\hline \multicolumn{9}{|l|}{ Apparent nutrient digestibility $\left(\mathrm{gkg}^{-1}\right)$} \\
\hline Dry matter & 684.9 & 650.0 & 528.0 & 500.0 & 15.2 & * & NS & NS \\
\hline Crude protein & 677.5 & 655.0 & 555.5 & 480.0 & 45.7 & * & * & NS \\
\hline Ether extract & 633.5 & 630.0 & 610.0 & 642.5 & 6.8 & NS & NS & NS \\
\hline Crude fibre & 463.5 & 440.0 & 504.0 & 510.0 & 16.7 & NS & * & NS \\
\hline Ash & 350.0 & 360.0 & 450.0 & 500.0 & 36.1 & * & NS & NS \\
\hline
\end{tabular}

${ }^{1}$ Probability for Linear (L), Quadratic (Q) and Cubic trend (C); NS: Not significant; ${ }^{*} p<0.05 ;{ }^{* *} p<0.01$. 


\section{OSO, OLAYEMI, BAMGBOSE AND FOWOYO}

digestibility and crude protein digestibility reduced with increase in FCSM inclusion from $684.9 \mathrm{gkg}^{-1}$ and $677.5 \mathrm{gkg}^{-1}$ to $500 \mathrm{gkg}^{-1}$ and $480 \mathrm{gkg}^{-1}$ respectively. Birds fed control diet had higher values of $(\mathrm{L}, \mathrm{Q} ; \mathrm{p}<0.05)$ crude protein digestibility than the rest dietary treatments. The effect of reduced linear $(p<0.05)$ dry matter digestibility and crude protein digestibility $(\mathrm{L}, \mathrm{Q} ; \mathrm{p}<0.05)$ reported in this study could be attributed to the effect of residual ricin- an antinutritional factor in castor oil bean. Ricin has been shown to interfere with digestion of nutrient, absorption and nutrient utilization. The reduced digestibility values observed could also be due to the increasing fibrous nature of the diet as FCSM inclusion increased (Longe and Ogedengbe, 1989).

\section{HaEmatological parameters, SERUm BIOCHEMISTRY AND CARCASS CHARAC- TERISTICS}

The haematological and carcass characteristics of cockerel chicks shown in table IV revealed no significant effect on packed cell volume (PCV), haemoglobin ( $\mathrm{Hb})$, red

Table IV. Haematological indices, serum biochemistry and carcass yield of cockerel chicks fed experimental diets. (Índices hematológicos, bioquímica sérica y rendimiento canal de pollos alimentados con las dietas experimentales).

\begin{tabular}{|c|c|c|c|c|c|c|c|c|}
\hline \multirow[b]{3}{*}{ Parameters } & \multicolumn{4}{|c|}{ Levels of inclusion of FCSM $\left(\mathrm{gkg}^{-1}\right)$} & \multirow[t]{3}{*}{ SEM } & \multicolumn{3}{|c|}{ Probability $^{1}$} \\
\hline & 0 & 50 & 100 & 150 & & L & Q & C \\
\hline & T1 & T2 & T3 & T4 & & & & \\
\hline \multicolumn{9}{|l|}{ Haematological indices } \\
\hline Packed cell volume (\%) & 37.58 & 36.62 & 37.01 & 36.75 & 0.18 & NS & NS & NS \\
\hline Haemoglobin (g/dl) & 13.19 & 13.42 & 13.29 & 13.20 & 2.60 & NS & NS & NS \\
\hline Red blood cell $\left(\times 10^{6} / \mathrm{mm}^{3}\right)$ & 9.01 & 8.95 & 8.62 & 8.51 & 0.12 & NS & * & NS \\
\hline White blood cell $\left(\times 10^{6} / \mathrm{mm}^{3}\right)$ & 6.00 & 6.10 & 6.31 & 6.25 & 0.07 & $* *$ & * & NS \\
\hline Neutrophil (x 109/l) & 0.21 & 0.20 & 0.20 & 0.22 & 0.005 & NS & NS & NS \\
\hline Eosinophil(x 109/l) & 0.30 & 0.35 & 0.29 & 0.30 & 0.014 & NS & NS & NS \\
\hline Basophil(x 109/l) & 0.11 & 0.12 & 0.13 & 0.15 & 0.008 & NS & * & NS \\
\hline Platelets (x 10\%) & 210.50 & 219.10 & 228.10 & 226.50 & 3.49 & ** & * & NS \\
\hline \multicolumn{9}{|l|}{ Serum biochemistry } \\
\hline Total serum protein $(\mathrm{g} / \mathrm{l})$ & 60.00 & 61.20 & 59.00 & 61.46 & 0.49 & NS & NS & NS \\
\hline Serum albumin (g/l) & 41.00 & 39.20 & 37.00 & 39.50 & 0.72 & NS & NS & NS \\
\hline Serum globulin (g/l) & 19.00 & 22.00 & 22.00 & 21.96 & 0.62 & NS & * & NS \\
\hline Uric acid $(\mathrm{mg} / \mathrm{dl})$ & 42.91 & 42.43 & 42.06 & 41.70 & 0.22 & NS & NS & NS \\
\hline Creatinine (mg/dl) & 0.55 & 0.54 & 0.67 & 0.79 & 0.05 & ** & * & NS \\
\hline \multicolumn{9}{|l|}{ Carcass characteristics } \\
\hline Plucked weight (g/bird) & 450.0 & 400.0 & 375.0 & 367.0 & 16.19 & * & NS & NS \\
\hline Eviscerated weight (g/bird) & 386.5 & 343.5 & 317.0 & 311.0 & 14.88 & * & NS & NS \\
\hline Back weight (g/bird) & 75.0 & 60.5 & 51.2 & 55.0 & 4.50 & * & * & NS \\
\hline Drumstick weight (g/bird) & 28.0 & 24.0 & 21.5 & 21.1 & 1.37 & NS & NS & NS \\
\hline Breast weight (g/bird) & 61.2 & 61.0 & 59.1 & 55.1 & 1.22 & * & NS & NS \\
\hline Gizzard weight (g) & 15.0 & 14.6 & 15.5 & 16.0 & 0.91 & NS & NS & NS \\
\hline Small intestine weight $(\mathrm{g})$ & 15.8 & 17.0 & 16.7 & 17.1 & 1.37 & NS & NS & NS \\
\hline Large intestine weight $(\mathrm{g})$ & 3.0 & 2.5 & 3.1 & 4.0 & 0.27 & NS & NS & NS \\
\hline
\end{tabular}

${ }^{1}$ Probability for Linear (L), Quadratic (Q) and Cubic trend (C); NS: Not significant; ${ }^{*} p<0.05 ;{ }^{* *} p<0.01$.

Archivos de zootecnia vol. 60, núm. 229, p. 80. 


\section{UTILISATION OF CASTOR SEED MEAL IN COCKEREL CHICKS}

blood cell (RBC), neutrophil, eosinophil, basophil, total serum protein, serum albumin, serum globulin and serum uric acid. However FCSM inclusion revealed a significant $(\mathrm{L}$; $\mathrm{p}<0.01 ; \mathrm{Q} ; \mathrm{p}<0.05$ ) effect on white blood cell $(\mathrm{WBC})$, platelet $(\mathrm{Pl})$ and serum creatinine with their values increasing as FCSM inclusion increased from $6.0 \times 106 / \mathrm{mm}^{3}, 210.5$ $\mathrm{x} 109 / 1$ and $0.55 \mathrm{mg} / \mathrm{dl}$ in chicks fed control diet to $6.25 \times 106 / \mathrm{mm}^{3}, 226.5 \times 109 / 1$ and 0.79 $\mathrm{mg} / \mathrm{dl}$ respectively in chicks fed $150 \mathrm{gkg}^{-1}$ FCSM diet. WBC has been known to play an important role with the production of antibodies and recognition of foreign bodies (Eggum, 1989). Values recorded were still within the normal range for birds. The increase in WBC values as FCSM inclusion increased has been attributed to a physiological efforts of the birds in increasing its immunity after a lowered immunity caused by the deleterious factors in castor bean. High values of WBC have been found in infectious inflammatory conditions, under stress conditions, in association with allergy, parasitism and chronic tissue damage (Eggum, 1989). Increased blood platelet production could be as a result of increasing physiological stress created in the birds as FCSM inclusion increased. Marked increase in thrombopoiesis has been linked with stress, occlusion of large vessels, chronic inflammatory disease and iron deficiency (MacWilliam et al., 1982). Jacobs (1966) reported a positive relationship between erythrocyte and blood

\section{REFERENCES}

Adedeji, J.A., Apata, D.F., Aderinola, O.A., Rafiu, T.A. and Amao, S.R. 2006. Performance and haematological/serum characteristics of rabbits fed boiled castor seed cake based diet. World J. Zoology., 1: 91-93.

Aduku, A.O. 1993. Tropical feedstuff analysis tables. In: Notes on feedstuff analysis table. ABU-Samaru. Zaria. Nigeria.

Aduku. 2000. Tropical feedstuff analysis table. Faculty of Agriculture. Ahmadu Bello University. platelets production. Blood platelets values of chicks placed on the control diet and 50 gkg $^{-1}$ FCSM were similar with close range and differs widely from those on 100 and 150 $\mathrm{gkg}^{-1}$ FCSM based diet. The higher $(\mathrm{p}<0.05)$ values of creatinine obtained in chicks fed 100 and $150 \mathrm{gkg}^{-1}$ is an indication of muscle wastage in the chicks due to treatment imposed. Serum creatinine levels indicate the extent of muscle degradation in animals. When the vales are high, it shows a high degradation of muscle phospho-creatinine to form creatinine and the values varies from $0.50-1.35 \mathrm{mg} / \mathrm{dl}$ (MacWilliam et al., 1982). The findings in this study was contrary to the report of Ani and Okorie (2002) who reported higher $(\mathrm{p}<0.05)$ packed cell volume (PCV) in birds fed 0,10 and $15 \mathrm{gkg}^{-1}$ castor bean meal $(\mathrm{CBM})$ diets.

The result of the carcass characteristics shows that the plucked weight, breast weight and eviscerated weight reduced significantly $(\mathrm{L} ; \mathrm{p}<0.05)$ as FCSM inclusion level increased in the diet. Back weight also reduced significantly (L, Q; $<<0.05)$ as FCSM inclusion level increased in the diet The reduction in carcass weight was as a result of reduced weight gain and final live weight which later translated into reduced carcass and cut parts weight.

In conclusion, FCSM could be included at $50 \mathrm{gkg}^{-1}$ level inclusion in starting cockerels without any deleterious effect on growth response, nutrient digestibility, haematological parameters and carcass yield.

Zaria. Nigeria.

Anandan, S., Anil Kumar, G.K., Ghosh, J. and Ramachandra, K.S. 2005. Effect of different physical and chemical treatments on detoxification of ricin in castor cake. Anim. Feed Sci.Techn., 120: 159-68.

Ani, A.O. and Okorie, A.U. 2002. Nutritive value of dehulled and cooked castor oil bean meal to broiler finishers. Proc. $27^{\text {th }}$ Conference of NSAP. Akure. Nigeria. pp. 141-143. 


\section{OSO, OLAYEMI, BAMGBOSE AND FOWOYO}

AOAC. 1990. Methods of analysis. $16^{\text {th }}$ ed. Association of Official Analytical Chemists. Washington, D.C.

Baker, F.J. and Silverton, R.E. 1985. Introduction to medical laboratory. $6^{\text {th }}$ ed. Butterworth and Co Publishing. London. pp. 523-531.

Bonsnes, R. and Tausslay, H.H. 1945. Colorimetric determination of creatinine by Jaffe reaction. $J$. Biochem., 158: 581-591.

Carrielo-Gama, C. 2006. Development of a technology to disable allergens of Ricinus communis (castor bean). Monografia. Centro para Biociencias e Biotecnologia. Universidade Estadual do Norte Fluminense. Rio de Janeiro. Brasil.

Colowich, S.P. and Kaplan, N.O. 1955. Method in enzymology. Vol. 1. $2^{\text {nd }}$ ed. New York Academic Press. New York.

Eggum, B.O. 1989. Biochemical and methodology principles in protein metabolism in farm animals. $1^{\text {st }}$ ed. University Press. Berlin. pp. 20.

Gibson, R.M., Bailery, C.A., Kubena, L.F., Hull, W.E. and Harvey, R.B. 1989. Ochratoxin and dietary protein. Effect on body weight, feed conversion ratio and mortality in 3 weeks day old broiler. Poultry Sci., 68: 1658-1663.

Gomez, A.K. and Gomez, A.A. 1983. Statistical procedure for agricultural research. $2^{\text {nd }}$ ed. International Rice Research Institute. The Phillipines. pp. 46.

Jacobs, H.S. 1966. A pathogenic classification of the anaemia. Med. Clin. Nutri. Am., 50: 1679-1689.

Jerkins, J.P. 1963. Allergenic and toxic components of castor oil bean meal: Review of literatures and studies of inactivation of these components. J. Sci. Food Agric., 14: 773-780.

Longe, K. and Ogedengbe, A., 1989. Influence of fibre on metabolizable energy of diets and performance of growing pullets in the tropics. Brit. Poultry Sci., 30: 1193-1195.

Machado, O.L.T. and Silver, J.G., 1992. An allergenic $2 S$ storage protein from Ricinus communis seeds which is part of the albumin precursor predict by c-DNA data. Braz. J. Med. Biol. Res., 25: 567-582
MacWilliam, P.S., Seary, I. and Balley, J.E. 1982. Bovine post parturient haemoglobinuria. Can. Vet. J., 23: 309-312.

Margeret, L., Vickery, O.O. and Brian, N. 1979 Plant products of tropical Africa. $2^{\text {nd }}$ ed. Machmillan Press Ltd. New York.

Okorie, A.U., Anugwa, F.O.I., Anamelechi, G.C. and Nwaiwu, J. 1985. Castor bean: a potential livestock protein supplement in the tropics. Nutr. Rep. Int., 32: 659-666.

Okorie, A.V., Ennuraoye, F. and Anugwa, O.I., 1987. Response of broiler ducks to graded level of heat treated castor oil bean. Archiv. Genflugerkunde, 52: 127-132.

Okoye, J.O.A., Enunwonye, C.A., Okorie, A.U and Anugwa, F.O.I. 1987. Pathological effect of feeding roasted castor bean meal to chicks. Avian Pathol., 16: 283-290.

Oluyemi, J.A and Robert, F.A. 1979. Poultry production in warm climate. Macmillian Press. London. pp. 70.

Pablo, F., Polit, O. and Valdemir, O. 1976. Biochemical and nutritional property of castor bean protein. J. Agr. Food Chem., 24: 295-299.

Puttaraj, S., Bhagya, K.N., Murphy, N. and Sighn, O. 1993. Effect of detoxification of castor seed (Ricinus comunis) protein isolate on its nutritional quality. J. Sci. Food Agr., 30: 100-102.

SPSS. 1999. Statistical package for social scientist. SPSS for Microsoft Windows Release 6.0. User Manual. SPSS Inc. Chicago.

Thorpe, S.C., Kemedy, D.M., Panzani, R.C., Mc Gulr, B. and Lord, D.M. 1988. Allergy to castor allergy to castor bean II - Identification of the major allergens in castor bean seeds. J. Allergy Clin. Immun., 82: 62-72.

Varley, H., Van, E. and Kass, I. 1980. Practical clinical chemistry. Inter Science Publishers Inc. New York. pp. 197-240.

Vilhjalmsdottir, L. and Fisher, H. 1971. Castor bean meal as a protein source for chickens. Destruction and determination of limiting amino acids. $J$. Nutr., 101: 1185-1192.

Wootton, T.D. 1964. Micro analysis in medical biochemistry. $4^{\text {th }}$ ed. Churchill Ltd. London.

Archivos de zootecnia vol. 60, núm. 229, p. 82. 